\title{
NURSES EXPERIENCE IN IMPLEMENTING A TRIAGE ON MASS VISITATION IN THE EMERGENCY DEPARTMENT OF NGANJUK DISTRICT HOSPITAL TYPE B
}

\author{
Agus Khoirul Fuadi', Retty Ratnawati ${ }^{2}$, Tony Suharsono ${ }^{2}$ \\ 1STIKES Satria Bhakti Nganjuk \\ ${ }^{2}$ Master of Nursing Program Faculty of Medicine Universitas Brawijaya
}

\begin{abstract}
Nganjuk district hospital is the referral hospital in Nganjuk, so the consequences that must be accepted is the potential of a patient mass visitation. Emergency Department is the front line that receive the patients. Mass visitation is a condition where there are lot of patients arrived at the same time, it is due to various causes or diseases. These factors include the increase number of referral patient's arrival, the increase number of patient's arrival at its own initiative, some disasterlaccident/plague victims, where they came to the emergency department with different criticalness. When the emergency room experiencing a mass visitation and exceeding the capacity that can be handled, it requires a triage to sort such patients according to its priority. This study was a qualitative research that used an interpretive phenomenological approach. The data were collected and analyzed by using a thematic analysis approach by Braun and Clarke. The study resulted in four themes, namely changed triage mechanism, triage system inadequate-yet, the expectation of emergency room policy changing, education for health advance strategies. Where finally, these themes are narrowed down to one major theme namely the spirit of change in the middle of inadequate triage system in mass visitation. The triage system was not adequate yet, this encouraged the triage nurses to change the triage mechanism, the requirement to implement an adequate triage system has encouraged the hopes of the nurses to change the policy in emergency department. However, they have already tried to prevent the problems all this time by putting forward a education for health strategy. These description indicated the dynamics of triage nurses in the emergency department of Nganjuk district hospital in the form of a spirit of change in the middle of inadequate triage system that was used to handle a mass visitation. The researchers recommend that Nganjuk district hospital should create master plan for the triage system to handle a mass visitation.
\end{abstract}

Keyword : Triage, mass visitation

Jurnal Ilmu Keperawatan, Vol. 6: No.1 Mei 2018; Korespondensi : Agus Khoirul Fuadi. STIKES Satria Bhakti Nganjuk Jl. Panglima Sudirman VI Nganjuk. Email : papajudika@yahoo.com 


\section{PENDAHULUAN}

Rumah sakit kelas $B$, Instalasi gawat darurat yang tersedia harus mampu memberikan pelayanan selama 24 jam secara terus menerus selama 7 hari dalam seminggu (Direktorat Bina Pelayanan Penunjang Medik Dan Sarana Kesehatan Kementerian Kesehatan RI, 2012).

Permasalahan muncul seiring dengan angka kunjungan ke ruang IGD yang sangat tinggi. Pada situasi kunjungan yang bersifat massal dan datang secara bersamaan, apabila tidak dilakukan penanganan dengan sistem management yang tepat, maka akan menyebabkan beberapa dampak negatif bagi pasien. Penelitian Richardson (2006) berdasar presentasi pasien di australia bahwa dalam kondisi yang sangat ramai akan menyebabkan penurunan kinerja pengobatan sesuai standart dan tingkat kematian yang lebih tinggi berdasar kategori triase.

Pada sebuah studi pendahuluan di ruang IGD RSUD Nganjuk pada tanggal 9 Desember 2015 dan 10 Desember 2015. Melalui sebuah wawancara dengan kepala ruangan dan mempelajari dokumentasi angka kunjungan pasien, menunjukkan data kunjungan pasien 2000 sampai 2400 pasien setiap bulannya, dan sebanyak $20 \%$ arus kedatangan pasien tersebut merupakan angka kunjungan masal, dengan jumlah kedatangan pasien antara 10 sampai 15 orang bahkan bisa melebihi, dimana waktu kedatangan mereka secara bersamaan, dengan karakteristik penyakit yang berbeda - beda dan dengan tingkat kegawatan yang berbeda - beda pula. Kejadian tersebut biasanya terjadi pada kunjungan sore, malam, hari libur dan setelah hari libur, serta pada situasi tertentu seperti kecelakaan dengan jumlah korban yang banyak, dan pada saat terjadi bencana.

Pada masa - masa yang akan datang, potensi kejadian kunjungan massal ini diprediksi akan semakin meningkat, dengan berlakunya BPJS kesehatan, Rumah Sakit Umum Daerah Kabupaten Nganjuk menjadi rujukan pertama pasien dari puskesmas maupun fasilitas kesehatan tingkat pertama. Ditambah dengan kedatangan pasien dengan inisiatif sendiri untuk mencari pengobatan, manakala dokter tutup pada malam hari atau pada hari libur, maka satu - satunya harapan mereka adalah datang ke IGD. Ketika mereka datang secara bersamaan,maka pasti akan terjadi kunjungan massal.

Berdasarkan pada kondisi dan situasi di atas, ketika terjadi kunjungan pasien secara massal atau kunjungan yang banyak dalam waktu yang bersamaan, dibutuhkan adanya proses pemilahan pasien sesuai dengan tingkat kegawatannya atau kita kenal dengan istilah triase. 0'Connor,et al (2014) triage dirasakan sangat berguna pada kondisi jumlah kunjungan pasien yang banyak dengan jumlah sumberdaya manusia yang terbatas.

Maka dari itu peneliti bermaksud melakukan penelitian tentang pengalaman perawat dalam melaksanakan triase pada kunjungan massal di Ruang IGD Rumah Sakit Tipe B RSUD Nganjuk, sebagai rumah sakit rujukan di Kabupaten Nganjuk. Tentang Bagaimanakah Makna Pengalaman Perawat Dalam Melaksanakan Triase Pada Kunjungan 
massal Di Ruang IGD Rumah Sakit Tipe B RSUD Nganjuk.

\section{METODE}

Penelitian ini menggunakan desain kualitatif fenomenologi, dengan endekatan interpretif. Lokasi penelitian adalah Ruang IGD Rumah Sakit Umum Daerah Kabupaten Nganjuk. Jumlah partisipan sebanyak 5 orang perawat yang sesuai krteria inklusi yaitu pengalaman kerja di IGD lebih dari 2 tahun, perawat yang ditunjuk di ruang triase, dan pernah melakukan triase, bersedia menjadi partisipan dan komunikatif. Partisipan yang yang didapatkan yaitu semua berjenis kelamin laki-laki dengan rentang usia 30-40 tahun, rentang pengalaman kerja 6-15 tahun. Partisipan tersebut berpendidikan terakhir D3 Keperawatan dan S1 keperawatan dan memiliki sertifikat pelatihan BLS, BTLS, PPGD, Triase, dan Emergency Nursing.

Analisa data yang digunakan dalam penelitian ini adalah analisa tematik dengan memperhatikan keabsahan data. Dalam peneltian kualitatif, keabsahan data merupakan usaha untuk meningkatkan derajat data (Speziale \& Carpenter, 2010). Proses keabsahan dalam penelitian dilakukan dengan cara melakukan konfirmasi terhadap informasi yang telah ditemukan.

Penelitian ini telah melalui review untuk memperoleh surat kelaikan etik dari Komisi Etik Poltekes Depkes Malang.

\section{HASIL PENELITIAN}

Tema - tema yang didapatkan dari analisis data Pengalaman Perawat Dalam melaksanakan triase pada kunjungan massal di ruang IGD rumah sakit rujukan pertama tipe B Rumah Sakit Umum Daerah Kabupaten Nganjuk yaitu :

1. Mekanisme Triase Berubah

2. Sistem Triase Belum Adequat

3. Mengharap Perubahan Kebijakan IGD

4. Mengedepankan Strategi KIE.

Tema - tema ini yang akhirnya mengerucut ke satu tema besar yaitu "Semangat Berubah Di Tengah Sistem Triase Yang Tidak Adequat Pada Kunjungan massal"

\section{Tema Mekanisme Triase Berubah}

Pada saat kunjungan massal, perawat merubah cara kerja dalam melakukan triase serta tindakan yang dibutuhkan. Tema ini dibangun dari dua sub tema yaitu Ruang Triase Ditiadakan dan Pengkajian Fokus dan Singkat

\section{Sub Tema Fungsi Ruang Triase Ditiadakan}

Perawat tidak memfungsikan ruang triase untuk memilah pasien yang datang ke IGD, namun Pasien langsung ditangani tanpa proses triase, semua pasien yang datang masuk ke ruang tindakan langsung.

"..datang secara bersamaan dalam kondisi-kondisi tertentu kan jadi overload, jadi semua langsung masuk ke dalam....(P3)"

"..Di luar tidak, karena tenaga sama triasenya jelas tidak seimbang. Ketimbang numpuk di depan, akhirnya kita masukkan semuanya..(P1)"

Perawat triase berperan ganda, dimana 
selain ditugaskan sebagai perawat triase ia juga dituntut untuk melakukan pekerjaan sebagai perawat pelaksana yang bertugas menangani pasien, atau mereka menyebut sebagai perawat eksekutor

"..Sulitnya begini, kalau pasien banyak atau bisa dalam kondisi tidak banyak mungkin ada 10 pasien, namun dia mempunyai tingkat kegawatan sama, kadang karena kita sebagai petugas Triase tapi juga sebagai petugas eksekutor..(P3)"

\section{Sub Tema Pengkajian Fokus dan Singkat}

Perawat ketika melaksanakan pengkajian untuk keperluan triase pada pasien kunjungan massal berupaya menggunakan komponen yang dianggap penting dengan harapan dapat mempersingkat waktu pengkajian.

"Kalau mungkin massal itu kita tidak bisa sepenuhnya pemeriksaan fisik keseluruhan, mungkin ya kita tetap melakukan tapi cuma sekilas saja, untuk lebih lanjutnya biasanya tidak...(P4)"

"..Visual, Cuma pengamatan, misal ini sadar atau terganggu kesadaran berarti langsung...(P1)"

Pada saat kunjungan massal pengkajian menggunakan anamnese keluhan utama saja, Dimana keluhan utama diharapkan mampu menunjukan secara singkat dan fokus tentang keluhan yang paling dirasakan

$$
\text { "..Ya kalau massal hanya }
$$
menggunakan keluhan utama...(P2)"

\section{Tema Sistem Triase Belum Adequat}

Makna dari belum adequat adalah belum mempunyai syarat atau belum sama harkatnya dengan sistem triase yang diharapkan.

\section{Sub Tema Pemakaian Model Triase Berbeda Antar Petugas}

Model triase selalu menjadi kesepakatan yang sama dalam penerapannya oleh satu rumah sakit, dan lazimnya menggunakan satu aturan model triase. Sesuai dengan hasil analisa data perawat yang dijumpai menggunakan istilah model triase yang berbeda - beda satu dengan lain. Penggunaan model triase yang berbeda ini tentunya menunjukkan belum adequatnya sistem triase yang berlangsung di IGD RSUD Nganjuk.

\section{Sub - Sub Tema Pemakaian Model Triase}

\section{Tingkat}

Model triase dua tingkat, kategori triase dua tingkat yang dipakai oleh perawat triase RSUD Nganjuk adalah sadar dan tidak sadar serta satu kategori lagi adalah trauma dan non trauma.

"....Selama ini massal itu tetap tidak sadar dan sadar, tidak apa apa". Ya tidak masalah... (P1)"

“... Jadi kita pilahkan kalau kejadian seperti itu yang trauma masuk trauma dan yang non trauma masuk non trauma... (P3)"

\section{Sub - Sub Tema Pemakaian Model Triase \\ 5 Tingkat}

Model ini menggunakan 5 tingkatan yaitu resusitasi, emergency, urgen, non urgen 
dan fals emmergency. Kategori ini adalah kategori yang sebenarnya saat ini berlaku di Ruang IGD RSUD Nganjuk, namun perawat triase di Rumah Sakit Nganjuk menyatakan tidak semua mengggunakan model triase ini

“.. Kalau disini menggunakan lima tingkat, ada resusitasi, emergency, urgen, non urgen sama fals emergency...(P2)"

\section{Sub -Sub Tema Pemakaian Model Triase}

\section{Tingkat}

Makna triase tiga tingkat adalah penggolongan tingkat kegawatan pasien ke dalam tiga kategori yaitu P1 adalah prioritas pertama, P2 adalah prioritas kedua dan P3 adalah prioritas ketiga. Pengkategorian ini didapat oleh perawat RSUD Nganjuk dari pelatihan yang dilakukan terbaru.

".. Untuk sekarang kita menggunakan

P1, P2, dan P3... (P4)"

Pernyataan ini membingungkan karena pada format pengkajian di IGD RSUD Nganjuk digunakan 5 tingkat kategori.

\section{Sub Tema Label Kegawatan Pasien Tidak Tampak}

Makna label kegawatan pasien tidak tampak adalah tidak bisa dilihat dengan indera mata. Beberapa hal yang mengindikasikan penyebab sistem pelabelan tidak tampak adalah pertama semua kategori triase bercampur tempatnya

"..lya langsung begitu, jadi akhire tempatnya yang campur aduk".. (P1)"

Pengggunaan ruang P1 atau ruang prioritas pertama untuk prioritas lebih rendah, ruangan prioritas 1 bisa digunakan untuk pasien yang bukan kategori P1

"... tapi kalau ada pasien trauma atau pasien cuma vulnus app gitu, mengerjakan dimasukkan ke ruang lama yang dijadikan P1...(P2)"

Wujud dari ketidakonsistenan lain adalah pemisahan pasien, berupa pasien trauma atau non trauma.

"..Ya, kalau dia trauma ya trauma, kalau non trauma ya... maksudnya pisahkan antara trauma dan non trauma begitu saja...Ya, itu yang bikin menumpuk...(P3)"

Pernyataan partisipan tersebut menunjukkan bahwa terjadi penumpukan tanpa diketahui mana pasien yang menjadi prioritas. Rumah sakit sedang mencari bentuk triase yang dianggap sesuai, mengakibatkan perawat bingung terhadap sistem mana yang harus diterapkan.

"...Kalau di UGD sini masih dalam proses perbaikan tentang triase, jadi selama ini kita jalan dan kita bagi sendiri, kalau sekarang trauma di trauma itu kita jadikan P1 yang non trauma kita jadikan pembagian P2 dan P3, nanti kita kondisikan... (P4)"

Dari hasil ulasan diatas menunjukkan sistem triase yang belum adequat

\section{Sub Tema Keputusan Triase Sering Berbeda}

Hasil triase sering berbeda menunjukkan adanya ketidaksamaan antara petugas.

"..Kalau seperti itu ada, pernah, kategori gawat dikategorikan tidak 
gawat,ya kacau... Sering, cara menilainya sering.. (P1)"

Penyebab keputusan triase yang berbeda juga karena terjadi perbedaan keputusan dengan dokter sebagai penentu akhir.

".. Pernah Pak... Kalau kita mengkategorikan P1, tapi dokternya P2 bisa jadi kan seperti itu...(P2)"

Penyebab perbedaan hasil triase lainnya adalah karena permintaan perlakuan istimewa dari pasien, karena kiriman dari pejabat dan Lembaga Swadaya Masyarakat (LSM).

"..Kalau yang seperti itu sering Pak...banyak faktor yang mempengaruhi, contoh kayak kiriman-kiriman dari pejabat, LSM... (P3)"

Perbedaan hasil triase juga bisa terjadi karena perjalanan penyakit

"...mungkin dari depan cuma keluhan nyeri tapi sampai dalam dengan pemeriksaan lebih lanjut itu bisa menuju ke jantung dan akhirnya ke $P 1 \ldots$ Ya, sering terjadi sama stroke biasanya... Kalau yang P3, berubah jadi P1, kadang ada, kadang sulit untuk mengkomunikasikan...(P4)"

Maka dari itu berbagai penyebab diatas mengakibatkan sistem triase yang ada di ruang IGD RSUD Nganjuk termasuk pada makna yang tidak adequat.

\section{Tema Mengharapkan Perubahan Kebijakan IGD}

Perawat mengharapkan akan diterapkan triase pilihan yang dianggap paling tepat diaplikasikan di ruang IGD RSUD Nganjuk.
Sub Tema Mengharap Kepastian Sistem Triase

Harapan yang diminta adalah Sistem triase harus sesuai dengan pelatihan.

"..Komitmen dari managemen yang penting, karena managemen diatas harus komitmen kalau memang dirubah dengan Triase yang sekarang, atau memang yang terakhir,.(P1)"

Penentuan sistem triase hasil pelatihan harus segera direalisasikan, terutama pelatihan yang menerapkan kategori pasien dengan 3 kategori yaitu P1,P2,P3.

"..memang ini rencananya kita mau menuju kesana, itu memang harus ada $P 1, P 2$, dan seterusnyan itu, karena teman-teman setelah pelatihan kita harus menyamakan persepsi yang rencananya kita gunakan memang itu nanti P0, P1, P2, P3..(P3)"

\section{Sub Tema Mengharap pemenuhan kebutuhan SDM}

Ketersediaan Sumber Daya Manusia saat ini tersedia dirasakan kurang

"..Yang pertama tenaga..(P1)"

"..Harapannya, untuk saat ini kan kekurangan tenaga, ya ada penambahan tenaga, begitu..Untuk triase cuma ada 1 orang yang di dalam hanya 3 orang..(P2)

Mengharapkan adanya pelatihan dan simulasi yang berkesinambungan.

"... Kalau untuk meningkatkan Triase masal harus satu.. harus simulasi..(P1)" 
“..Kayak SDM nya..Ya, paling tidak sesuai standarnya, kalau UGD paling tidak sudah punya PPGD..(P2)"

Harapan lain adalah perlu adanya tim cadangan yang siap siaga

"...Misalkan, untuk kejadian masal memang perlu banget misalkan teman dari belakang untuk naik ke atas untuk naik ke triase..(P4)"

\section{Sub Tema Mengharap Pembenahan ruang IGD}

Ruang UGD kurannya kurang luas, sehingga membutuhkan penambahan ukuran.

"Triase seperti ini, ruangannya juga tidak terlalu lebar kan, ..(P1)"

"..Kendalanya ruang dalam juga kurang..(P2)"

".. Selama ini masih keterbatasan tempat..(P4)"

Ruangan tidak sesuai dengan penataan yang diharapkan, khususnya kesesuaian pembagian ruangan dengan tuntutan pelatihan yang telah dilaksanakan.

"...manajemen harus bisa menata ruangan agar bisa lebih sesuai..(P3)"

"...selama ini kita di UGD memang belum sesuai yang diharapkan, yang diinginkan tempat..(P4)"

Tema Mengedepankan Strategi Komunikasi, Informasi dan Edukasi (KIE) Sub Tema KIE Berkali-kali Pada Satu Pasien

Sub tema ini dibangun oleh dua sub sub tema yaitu yang pertama sub - sub tema tuntutan KIE lebih dari satu kali dan yang kedua adalah pasien dengan atribut tertentu susah diberi KIE

\section{Sub - Sub Tema Permintaan KIE Lebih Dari Satu Anggota Keluarga}

Membutuhkan KIE pada keluarga yang berbeda - beda karena keluarga yang datang tidak bersamaan,

"..Biasanya nanti yang protes keluarga yang lainnya, kita sudah jelaskan, misalkan yang sakit istri kita jelaskan ke suaminya tapi yang protes orang ketiga biasanya anaknya atau saudaranya..Ya, mau tidak mau kita menjelaskan lagi..(P3)"

\section{Sub - sub tema Pasien Dengan Atribut Istimewa Sukar Diberi KIE}

KIE sangat sulit pada pasien yang harus dianggap istimewa.

"..Ya, tapi dalam kondisi-kondisi tertentu memang sulit apalagi karakteristiknya orang-orang kan dibilangnya tidak bisa..Ya, LSM tambah sulit lagi..(P3)"

\section{Sub Tema Pasien Prioritas 3 Sasaran utama KIE}

Pasien prioritas tiga sasaran utama KIE.

"..Selagi kita meng-KIE-nya bagus, insyaAllah tidak, makanya yang untuk P3 betul-betul di-KIE..Setelah dia ditentukan P3, P3 harus segera di KIE..(P2)"

Menunggu resep menyebabkan pasien P3 lama di ruang IGD.

"..Maksudnya dalam penanganan ya. Kan datang diperiksa mungkin P3 yang lama menunggu resepnya..(P3)" 


\section{Sub Tema KIE Mencegah Komplain}

Komplain dicegah melalui KIE dan harus dilakukan segera begitu pasien masuk pada kategori tidak gawat.

"..Ya, kalau kita lupa menjelaskan ya sudah sini dulu, mengapa kok didiamkan saja..Lebih emosi Mas, maunya berobat kok dudukduduk..Tapi untuk yang P3 tetap harus kita jelaskan, kesannya kalau nanti tidak dijelaskan pemikiran orang dia ditelantarkan, makanya perlu ada penjelasan..(P2)"

KIE hendaknya didahului pemeriksaan awal, Sebelum KIE setidaknya dilakukan pemeriksaan TTV

"..Selama ini yang kita lakukan tetap yang pertama intinya kesalahpahaman timbul dari komunikasi, jadi kita tetap komunikasi, tetap misalkan untuk pasien-pasien panas tetap usahakan untuk melakukan TTV lah sedikitnya untuk itu, terus kita komunikasi bahwa ada yang lebih gawat penangannya..(P4)"

\section{Sub Tema Kebutuhan Petugas Khusus KIE}

Selama ini dokter pelaksana tindakan sekaligus pemberi KIE, makna dari pernyataan ini adalah pelaksanaan KIE biasanya dilakukan oleh dokter setelah tindakan ke pasien lain. Hal ini mengandung makna bahwa KIE tidak bisa dilakukan segera dan sewaktu - waktu ketika pasien atau keluarga membutuhkan.

"..Tidak, ini biasanya KIE dulu, kalau dokter sudah menangani yang tidak sadar selesai, baru ini yang terakhir, sampai 15 - 30 menit tidak masalah, yang penting kan KIE, komunikasinya yang enak kan ndak masalah...Dokter jaga juga bisa..(P1)"

Kepala jaga sekaligus petugas triase sebagai pemberi KIE. Hal ini tentunya tidak serta merta akan mempunyai cukup waktu untuk mengambil peran juga sebagai petugas KIE.

"..Ya, paling tidak itu yang paling

bisa menghandel adalah kepala jaga...(P3

\section{Hubungan Antar Tema}

Tema-tema yang muncul tersebut terintegrasi dalam tema yaitu semangat perubahan di tengah sistem triase yang tidak adequat pada kunjungan massal. Keterkaitan masing masing tema dapat dijelaskan berikut ini.

Ketika terjadi kunjungan massal, maka perawat triase berupaya untuk mengubah mekanisme triase, upaya ini dilakukan dengan cara ruang triase ditiadakan dimana pasien langsung ditangani tanpa proses triase atau dilakukan penilaian kegawatan bersamaan dengan tindakan di ruang tindakan, hal ini diakibatkan petugas triase kewalahan akibat ketidakseimbangan kapasitas petugas dengan jumlah pasien yang datang, disamping adanya tuntutan bahwa perawat triase berperan ganda sebagai petugas eksekutor atau perawat pelaksana. Perubahan mekanisme triase yang lain tampak dari upaya perawat untuk melakukan pengkajian fokus dan singkat, dimana yang dikembangkan adalah pengkajian menggunakan inspeksi tingkat kesadaran saja kemudian pengkajian menggunakan anamnese 
keluhan utama saja dan pengkajian secara singkat.

\section{Penyebab dari upaya merubah} mekanisme triase tersebut dilatarbelakangi akibat adanya sistem triase yang belum adequat. Ketidakadequatan sistem triase dapat tergambar dari pemakaian model triase berbeda - beda antar petugas dimana ada yang menggunakan model triase 2 tingkat, ada yang menggunakan model triase 5 tingkat dan ada yang menggunakan model triase 3 tingkat sesuai dengan hasil pelatihan yang mereka dapatkan.

Bentuk ketidakadequatan sistem triase juga bisa tergambar dari sistem pelabelan pasien yang tidak tampak. Semua tingkatan triase bercampur tempatnya, selain itu pengggunaan ruang P1 untuk pasien dengan prioritas lebih rendah, pemisahan pasien bukan berdasar peringkat kegawatannya, serta rumah sakit sedang mencari sistem triase yang sesuai, sehingga hasil pelatihan belum sama dengan kondisi real sistem dan ruang IGD saat ini, yang menimbulkan penafsiran dan pengunaan sistem triase yang berbeda antara petugas satu dengan yang lainnya.

Keputusan triase yang sering berbeda juga termasuk bentuk dari ketidakadequatan sistem triase yang ada. Hal ini terbukti dengan adannya keputusan tingkat kegawatan sering salah, perbedaan keputusan dengan dengan dokter, perbedaan hasil triase karena permintaan perlakuan istimewa, perbedaan hasil triase karena perjalanan penyakit.

Maka dari itu perawat triase mengharap perubahan kebijakan IGD, harapan tersebut berupa mengharap kepastian sistem triase yaitu mengharap kesamaan sistem triase dengan pelatihan, mengharap realisasi hasil pelatihan, mengharap persamaan persepsi sistem triase yanng dipakai. Harapan lain terkait perubahan manajemen IGD berupa mengharap pemenuhan kebutuhan SDM berupa mengharap penambahan jumlah tenaga IGD, mengharap pelatihan dan simulasi berkelanjutan, mengharap tim cadangan yang siap siaga. Mengharap pembenahan ruang IGD yang didorong oleh luas ruangan belum memenuhi kebutuhan, penataan ruangan belum sesuai kebutuhan.

Ditengah kondisi dan berbagai hal diatas ternyata perawat triase sudah menerapkan upaya antisipasi yaitu mengedepankan strategi KIE karena tuntutan KIE berkali - kali pada satu pasien hal ini karena permintaan KIE anggota keluarga berbeda. Pasien dengan atribut istimewa sulit diberi KIE.

Strategi KIE juga memprioritaskan pasien P3 sebagai prioritas KIE. Hal ini karena memang sebagian besar pasien prioritas tiga sebagai sasaran utama KIE karena menunggu resep menyebabkan pasien P3 lama di ruang IGD, disamping itu karena menunggu ditangani menyebabkan pasien P3 lama di ruang IGD.

Upaya KIE pada dasarnya untuk mencegah adanya komplain karena beberapa sebab yaitu merasa datang lebih dulu sehingga marah bila tidak tertangani dulu, merasa ditelantarkan sehingga pasien emosi. Maka setiap KIE terlebih dahulu selalu dilakukan upaya pemeriksaan minimal TTV (tanda-tanda vital), yaitu tekanan darah, nadi dan respirasi. Namun upaya KIE ini mendapat sebuah hambatan sehingga mereka mengungkapkan tentang kebutuhan 
petugas khusus KIE sebab selama ini dokter pelaksana tindakan sekaligus pemberi KIE, kepala jaga sekaligus petugas triase sebagai pemberi KIE.

\section{PEMBAHASAN}

\section{Tema Mekanisme Triase Berubah}

Dibutuhkan tenaga yang profesional dalam triase, karena dengan pengetahuan dan pengalaman yang dimiliki, tenaga profesional akan memiliki intuisi dan keyakinan yang diliputi oleh kondisi profesional di dalam melakukan triase (James M. Ryan, 2005, Anderson, et al ,2006, Bolk, et al, 2007).

Dengan demikian pengambilan keputusan untuk menentukan kondisi kegawatan pasien harus menggunakan kerangka pikir profesional. Perawat yang terampil dan terlatih sangat dibutuhkan untuk menghindarkan kesalahan dalam penentuan kategori kegawatan pasien. Sehingga perawat triase di ruang IGD RSUD Nganjuk harus mampu meningkatkannya. Pada dasarnya kecepatan dan ketepatan pengkajian akan dipengaruhi oleh intuisi, semakin sering perawat triase RSUD Nganjuk melakukan triase maka dengan sendirinya akan terasah.

Pasien yang identik dengan kekuasaan dan atribut istimewa, telah mempengaruhi penentuan prioritas penanganan. Pasien pasien kerabat atau kiriman dari LSM (Lembaga Swadaya Masyarakat) dan kerabat atau kiriman - kiriman pejabat akan meningkatkan tekanan pada perawat triase, sehingga akan menentukan prioritas yang tidak seharusnya. Ini merupakan kesulitan tersendiri dan terbukti telah banyak menyita waktu perawat triase.

\section{Tema Mengharapkan Perubahan Kebijakan IGD}

Beberapa harapan yang muncul diantaranya adalah harapan tentang kepastian sistem triase yang digunakan. Sehingga mereka mengharapkan hasil pelatihan itu segera direalisasikan Master plan pembangunan ruang IGD RSUD Nganjuk, termasuk di dalamnya adalah ruang triase diselaraskan dengan pelatihan yang dilakukan, sehinggga tidak menimbulkan kebingungan bagi perawat dan petugas ruang IGD RSUD Nganjuk tentang sistem triase mana yang sebenarnya ingin dipakai rumah sakit.

\section{Tema Mengedepankan Strategi KIE}

Tuntutan KIE harus dilakukan berkali kali tidak terlepas juga dengan adanya beberapa pasien yang memang sukar untuk diberikan penjelasan, hal ini terjadi pada pasien-pasien yang memposisikan dirinya adalah pasien istimewa. Penilaian keistimewaan ini muncul karena pasien merasa bukan pasien BPJS sehingga ia memandang mempunyai sumberdaya keuangan dan bisa membiayai apapun yang dibutuhkan oleh pasien.

Demikian pula pada keluarga LSM yang biasanya seringkali memposisikan sebagai orang yang istimewa, dengan atribut kekuasaan yang dilekatkan oleh dirinya, bahwa ketika perawat tidak mendahulukannya maka artinya dalam tanda kutip mereka siap memperkarakan perawat dan petugas IGD atas layanan yang dinilai buruk. 
Hal ini semakin menunjukkan tentang pentingnya KIE di ruang IGD RSUD Nganjuk yaitu upaya melakukan komunikasi secara ramah. KIE dilakukan dengan menginformasikan kondisi pasien yang sebenarnya, serta memberikan edukasi bahwa dalam sistem triase tidak serta merta semua pasien harus ditangani segera. Perawat sudah menilai dengan indikator yang baku sehingga mampu menentukan pada kondisi yang mana sebenarnya tingkat kegawatan pasien, apakah pasien dalam kondisi gawat sehingga harus segera ditangani, ataukah kondisi tidak gawat yang sebenarnya bisa dilakukan penundaan tindakan, karena tim IGD sedang menangani pasien lain yang lebih gawat.

\section{Semangat Perubahan Ditengah Sistem Triase Yang Tidak Adequat pada kunjungan massal}

Menurut Robbins (2003) Perubahan yang telah direncanakan seringkali menimbulkan masalah yaitu adanya penolakan terhadap perubahan. Ada beberapa hal untuk menyelesaikan perubahan dimana salah satunya yaitu Komunikasi, dimana dengan komunikasi ini penolakan perubahan bisa dikurangi. Dengan komunikasi yang lebih baik, rencana perubahan akan dilihat sebagai realita yang lebih baik.

Maka dari itu semangat perubahan yang muncul pada perawat triase ruang IGD RSUD Nganjuk, hendaknya diwujudkan melalui komunikasi yang baik dengan penentu kebijakan terhadap ruang IGD RSUD Nganjuk dalam hal ini tentunya adalah kepala rumah sakit RSUD Nganjuk. Saluran komunikasi yang bisa digunakan adalah melalui pertemuan rutin ruang IGD RSUD
Nganjuk, dimana dari hasil pertemuan ini dicetuskan kesepakatan bersama yang dituangkan dalam draft usulan yang akan disampaikan kepada kepala rumah sakit melalui Kepala Bidang Keperawatan.

Perawat yang bekerja di instalasi gawat darurat hendaknya meningkatkan pengetahuan dan ketrampilan dalam triase untuk pengambilan keputusan triase yang tepat. Pengetahuan ini bisa dilakukan baik formal maupun informal (Levvasseur, 2002; Gerdtz, 2006). Maka kemudahan dalam mengikuti pelatihan akan membuat semangat perubahan semakin besar dan akan membantu pemecahan masalah yang dihadapi pada proses triase kunjungan massal.

\section{SIMPULAN}

Sesuai dengan hasil penelitian yang didapat maka terdapat 4 tema yaitu mekanisme triase berubah, sistem Triase belum adequat, mengharap perubahan kebijakan IGD, mengedepankan strategi KIE.

Dari keempat tema tersebut akhirnya mengerucut pada satu tema yaitu "Semangat perubahan di tengah sistem triase yang tidak adequat pada kunjungan massal.

Penelitian selanjutnya sebaiknya menggunakan metode studi kasus dengan melibatkan unsur lain sebagai sumber data dalam kejadian kunjungan massal di Ruang IGD RSUD Nganjuk seperti dokter, bidan, pasien, keluarga pasien.

Selain itu perlu dilakukan evaluasi terhadap pelaksanaan triase di IGD RSUD Nganjuk untuk memperbaiki pelayanan. 
DAFTAR PUSTAKA

Andersson, A.K Ombeerg, $M$, Svedlund, $M$. (2006) Triage In the Emergency Departement - a Qualitative study factor Which Nurses consider When making Decisions. Journal Compilation, Vol. 11, No.3 : 136 - 145.

Bolk, J. E., Mencl, F., Rijswijck, B. T. F. V., Simons, M. P., Vught, A. B. V. (2007). Validation of the emergency severity index (ESI) in self referred patients in a European emergency department. Emerg Med J. 24: 170-174.

Braun \& Clarke (2006). Using thematic analysis in psychology. Qualitative research in psychology, 3 (2), 77-110.

Department by Simulation, Departement Of Emergency Journal : 23 .321-330.

Direktorat Jenderal Bina Upaya Kesehatan Kementrian Kesehatan RI (2011). Juknis SIRS, Sistem Informasi Rumah Sakit. www.buk.depkes.go.id diakses tangal 7 Agustus 2016

Gerdtz MF, Bucknal TK (2006) Australian Triage Nurses Decision Making and scpe of Practice, Australian Journal of Advanced Nursing 18(1): 24-33

James M. Ryan (2008). Triage; Principes And Presures, Europe Journal Trauma Emergency Surgery : 34. 427-432.

Levvaseur S, Considine J, Charles A, Castle C (2002). Development of Physiological discriminator, for the Australian Triage Scale. ACICD Emergency Nurse, 10: 221234

Peraturan Menteri Kesehatan RI Nomor 75 Tahun 2014 tentang sarana dan prasarana Instalasi Gawat Darurat: Jakarta.

Richardson D, Drew B (2006). Increase in patient mortality at 10 days associated with emergency department overcrowding. MJA 184(5)

Robbins, Sthephen P. (2003).Perilaku Organisasi, edisi kesepuluh,PT Indeks.

Speziale, H.J.S and carpenter, D.R (2007). Qualitative Research In Nursing Advancing The Humanistic Imperative 4th Ed. Philadelpia: Lippincot Williams and Wilkins. 